\title{
PENGELOLAAN PEMBELAJARAN MODEL PROBLEM BASED LEARNING DENGAN MEDIA AUDIO-VISUAL UNTUK MENINGKATKAN KOMPETENSI BIOLOGI
}

\author{
Yosi Skanda Mirza \\ SMA Negeri 10 Bogor
}

Email: yosismirza@yahoo.co.id

\begin{abstract}
Abstrak:
Penelitian ini tergolong penelitian tindakan kelas yang dilaksanakan di SMA Negeri 10 Bogor. Penelitian mengambil subjek siswa kelas XI IPA 2 Tahun Pelajaran 2016/2017. Pengelolaan pembelajaran model Problem Based Learning dengan media Audio-visual bertujuan untuk meningkatkan kompetensi Biologi dan keantusiasan belajar siswa. Penelitian dilakukan sebanyak dua siklus. Siklus I terdiri dari 2 kali tindakan hasilnya rata-rata nilai uji kompetensi kognitif siswa 74. Hasil uji kompetensi kognitif siswa belum mencapai kriteria ketuntasan minimal yang telah ditetapkan. Kegiatan pembelajaran siklus II dilakukan dengan memperbaiki kelemahan yang ditemukan pada siklus I. Siklus II terdiri dari 2 kali tindakan hasilnya rata-rata nilai uji kompetensi kognitif siswa 79. Penelitian selesai pada siklus 2 karena hasil uji kompetensi siswa sudah melampaui kriteria ketuntasan minimal yang telah ditetapkan. Dari hasil pengolahan dan analisis data dapat disimpulkan bahwa pengelolaan pembelajaran model Problem Based Learning dengan Media Audio-visual dapat meningkatkan kompetensi Biologi tentang Sel dan Jaringan Tumbuhan pada siswa kelas XI-IPA 2 SMAN 10 Bogor.
\end{abstract}

\section{Kata kunci: Kompetensi, Model Problem Based Learning, Media Audio-visual}

\section{PENDAHULUAN}

Kompetensi yang hendak dicapai dalam pendidikan nasional adalah kecakapan hidup (life skill) dan keterampilan sikap. Setelah pembelajaran Biologi diharapkan siswa memiliki kecakapan vocational dan kecakapan sosial. Tujuan pembelajaran Biologi antara lain adalah agar siswa dapat dapat mengembangkan penguasaan konsep dan prinsip Biologi.

Pencapaian kompetensi siswa pada pelajaran Biologi di SMA Negeri 10 Bogor tergolong rendah karena persentase siswa yang mencapai Kriteria Ketuntasan Minimal (KKM) masih kecil. Hal ini terlihat dari hasil ulangan kenaikan kelas (UKK) Tahun Pelajaran 2013/2014 45\%, tahun Pelajaran 2014/2015 hanya $60 \%$ siswa yang mencapai KKM, Tahun Pelajaran
2015/2016 hanya 55\% siswa yang mencapai KKM.

Tantangan pembelajaran abad ke-21 adalah membuat pengetahuan tercermin sebagai perilaku yang terlihat dalam bentuk kemampuan memecahkan masalah. Proses pembelajaran hendaklah dirancang untuk mengaktifkan siswa, mengembangkan kreativitas, efektif namun tetap menyenangkan. Selain itu, perlu diciptakan Lingkungan Belajar yang kondusif dan bermakna yang mampu memberikan siswa keterampilan. Pembelajaran hendaknya menyenangkan, mencerdas, menguatkan, mampu mendorong siswa belajar lebih efektif dan mendalam, lebih kritis dan kreatif.

Beberapa hasil penelitian menunjukkan bahwa minat dan prestasi siswa meningkat secara 
drastis ketika terjadi proses berikut: a) siswa dibantu untuk membangun keterkaitan antara informasi (pengetahuan) baru dengan pengalaman (pengetahuan) lain yang telah dimiliki atau dikuasai, b) siswa diajarkan bagaimana mempelajari konsep, dan bagaimana konsep tersebut dapat dipergunakan di luar kelas, dan c) siswa diperkenankan untuk bekerja secara bersama-sama (cooperative).

Untuk mengatasi masalah di atas, dipandang perlu untuk diadakan penelitian tindakan kelas (classroom action research). Penelitian difokuskan terhadap " Pengelolaan pembelajaran model Problem Based Learning dengan Media Audio-visual untuk meningkatkan kompetensi Biologi tentang Sel dan Jaringan Tumbuhan pada siswa kelas XI-IPA 2 SMAN 10 Bogor Tahun Pelajaran 2016/2017”.

Istilah kompetensi memiliki beragam makna. Kompetensi merupakan karakteristik mendasar karena merupakan bagian yang mendalam dan melekat pada kepribadian seseorang. Kompetensi adalah pengetahuan atau keterampilan yang dapat menghasilkan output kunci berupa kemampuan melakukan suatu pekerjaan (Piscurich'1998).

Kompetensi adalah produk dari pengetahuan, keterampilan dan nilai-nilai. Siswa harus menunjukkan bahwa mereka telah menguasai nilai-nilai dan pengetahuan dengan menerapkan pengetahuan, keterampilan dan nilai-nilai dalam praktek. Tiga bidang utama kompetensi adalah keterampilan, pengetahuan, dan motivasi (Abate, 2010). Menurut Taksonomi Bloom, pengetahuan adalah tingkat dasar dari dimensi proses kognitif yang terdiri atas enam tingkat, yaitu pengetahuan (knowledge), pemahaman (comprehension), aplikasi (aplication), analisis (analysis), sintesis (synthesis), dan evaluasi (evaluation). Dimensi proses kognitif kemudian direvisi oleh Anderson menjadi mengingat (remembering), memahami (understanding), mengaplikasikan (applying), menganalisis (analysing), mengevaluasi (evaluating), mencipta (creating). (Forehand, 2011).

Kompetensi adalah produk dari pengetahuan, keterampilan dan nilai-nilai. (Hagan, 2007). Dalam dunia pendidikan, kompetensi didefinisikan sebagai tingkat prestasi siswa yang dikelompokkan berdasarkan skor yang dicapai. (Liu, 2009).

Berdasarkan teori-teori di atas, yang dimaksud dengan kompetensi adalah penguasaan dimensi-dimensi proses kognitif, yang akan mengarahkan dan mengendalikan perilaku siswa dalam bersikap, berpikir, dan bertindak.

Biologi adalah ilmu yang mempelajari tentang organisme hidup, mencakup ciri-ciri, fungsi, serta interaksinya. Sel adalah unit dasar kehidupan secara struktural dan fisiologis. Teori menyatakan bahwa semua kehidupan sel terdiri dari sel dan bahwa semua sel berasal dari sel yang sudah ada sebelumnya (Sadava, 2011). Biologi mempelajari asal-usul dan sejarah makhluk hidup, bagaimana makhluk hidup berinteraksi dengan satu yang lain, dan bagaimana fungsi makhluk hidup. Karakteristik kehidupan adalah: 1) Terdiri dari satu atau lebih. 2) Pada makhluk hidup bersel banyak, kelompok sel-sel khusus 
yang bekerja sama melakukan fungsi tertentu yang disebut jaringan. Kumpulan jaringan membentuk organ, yang melakukan fungsi tertentu. Sistem organ bekerja membentuk suatu organisme. 3) Tumbuh dan berkembang. 4) Bereproduksi. 5) Tanggap terhadap rangsangan. 6) Membutuhkan energi. 7) Menjaga homeostasis. 8) Beradaptasi 9) Berevolusi (Biggs,2008). Berdasarkan teori di atas biologi adalah ilmu yang mempelajari ilmu tentang organisme hidup yang dibentuk oleh sistem organ. Sistem organ merupakan kumpulan jaringan yang bekerja membentuk suatu organisme. Jaringan adalah kelompok sel khusus yang bekerja sama melakukan fungsi tertentu.

Pengetahuan tentang sel diawali dengan penemuan mikroskop oleh Robert Hook yang melihat sepotong gabus dari kulit kayu yang telah mati, terlihat struktur seperti kotak yang disebut cellulae berarti ruang kecil (Biggs,2008). Sel merupakan unit terkecil yang menyusun tubuh makhluk hidup dan tempat terselenggaranya fungsi kehidupan, yang terdiri atas: 1) Sitoplasma plasma sel adalah cairan sel yang bersifat koloid yang dibatasi oleh membran sel dengan lingkungan luar. Komponen penyusun sitoplasma terdiri atas sitosol yang bersifat koloid, sitoskeleton (rangka sel), dan organel-organel. 2) Organel sel terdiri atas nukleus, mitokondria, retikulum endoplasma, ribosom, golgi kompleks lisosom, peroksisom. 3) Perbedaan antara sel hewan dengan tumbuhan adalah dinding sel, vakuola permanen/vakuola sentral dan plastida. 4) Tansportasi sel merupakan gerakan zat melewati membran, dibedakan atas transpor aktif yang memerlukan energi dan transpor pasif tidak memerlukan energi untuk melewati membran plasma, seperti difusi dan osmosis.

Untuk mengenal susunan tubuh tumbuhan, kita perlu mempelajari susunan anatominya. Tubuh tumbuhan terutama tersusun dari kelompok-kelompok sel yang telah mengalami spesialisasi. Pada tumbuhan tingkat tinggi terdapat beberapa macam sel yang berbedabeda menurut fungsinya. Struktur tumbuhan berpembuluh terdiri atas tiga jaringan utama, yaitu dermis, pembuluh pengangkut, dan jaringan dasar (Ray, 2006). Jaringan tumbuhan dibedakan atas jaringan meristem dan jaringan permanen. Organ tumbuhan terdiri atas akar, batang, daun, dan bunga (modifikasi daun menjadi organ reproduksi). Tubuh tumbuhan terutama tersusun dari kelompok-kelompok sel yang telah mengalami spesialisasi. Struktur tumbuhan berpembuluh terdiri atas tiga jaringan utama, yaitu dermis, pembuluh pengangkut, dan jaringan dasar, yang terdiri atas: 1) Dermis terdiri atas epidermis, yaitu penutup tubuh tumbuhan dan periderm, merupakan jaringan pelindung pengganti epidermis pada tanaman yang mengalami penebalan sekunder. 2) Jaringan vaskuler terdiri atas floem (pembawa makanan) dan xilem (pembawa air). 3) Jaringan dasar terspesialisasi menjadi parenkim, kolenkim, dan sklerankim. Akar sesuai dengan berfungsinya mempunyai susunan anatomi yang terdiri atas epidermis, kortek, endodermis, silinder pusat. Batang sesuai 
dengan berfungsinya mempunyai susunan anatomi yang terdiri atas epidermis, korteks, endodermis, stele. Daun sesuai dengan fungsinya mempunyai susunan anatomi yang terdiri atas epidermis, parenkim (mesofil), dan ikatan pembuluh.

\section{Problem Based Learning merupakan} strategi instruksional di mana siswa secara aktif mengatasi masalah-masalah kompleks dalam situasi yang realistis. (Glazer, 2011). Siswa mendefinisikan masalah, mengumpulkan fakta, menghasilkan pertanyaan, berhipotesis, mengantisipasi informasi yang dibutuhkan, mengulangi masalah sehingga akhirnya menghasilkan solusi dan alasan-alasan yang direkomendasikan. (Fogarty, 1997). Problem Based Learning adalah suatu strategi instruksional dimana guru menyodorkan berbagai masalah kompleks dalam situasi realistis. Setelah menentukan masalah, siswa terlibat dalam penyelidikan untuk mengatasinya. Pembelajaran dilakukan dalam kerja kelompok. Selama pembelajaran, guru memfasilitasi investigasi yang meningkatkan pertumbuhan intelektual siswa.

\section{Problem Based Learning mengandung} parameter interaksi mediasi. Parameter interaksi mediasi yang terjadi dalam Problem Based Learning adalah: 1) Masalah berada dalam konteks dunia nyata yang kehadirannya bermakna, menawarkan tantangan dan kebaruan. 2) Terjadi interaksi dalam pemecahan masalah. 3) Pemecahan masalah proses transfer pembelajaran di seluruh konteks dan situasi. 4) Kerja kolompok menanamkan perasaan-perasan berhasil untuk menghapus rasa takut gagal yang tidak beralasan. 5) Mediasi praktek refleksi yang berhubungan dengan perilaku pengaturan diri. 6). Mediasi saling berbagi dan ketergantungan mengacu pada menanamkan rasa memiliki dan perilaku berbagi. (Oong-Seng, 2004).

Problem Based Learning terdiri dari:1) Guru menampilkan tayangan video untuk memunculkan masalah. 2) Siswa berdiskusi dalam kelompok untuk menentukan masalah.3) Siswa mengumpulkan fakta dan informasi tentang masalah yang akan dipecahkan, siswa mendiskusikan penyebab dan solusi dari masalah. 4) Siswa mempresentasikan penyebab dan solusi masalah. 5) Guru menfasilitasi siswa dalam mengambil kesimpulan penyebab dan solusi masalah.

\section{Keuntungan Problem Based Learning} antara lain: 1) Siswa terlibat dalam pembelajaran bermakna ketika berdiskusi. 2) Ketika siswa berupaya keras mencari solusi masalah, rasa tanggung jawab terhadap pembelajaran akan meningkatkan pengarahan diri. 3) Pemahaman dan keterampilan dalam konteks fungsional dapar diterapkan lebih baik dalam kehidupan. 4) Metode ini mengutamakan keterampilan-keterampilan interpersonal dan kerja tim. 5) Sikap Memotivasi diri sendiri karena menurut siswa pembelajaran berdasarkan masalah lebih menarik, merangsang, menyenangkan, cara belajar yang lebih fleksibel serta mengasuh. 6) Berdasarkan sudut pandang guru, pembelajaran berdasarkan masalah lebih 
menekankan pada pembimbingan sehingga peningkatan kontak antar siswa yang bermanfaat bagi pertumbuhan kognitif. Sama halnya dengan teori-teori belajar yang lain, terdapat keuntungan dan keterbatasan ketika mengembangkan atau mengimplementasikan kurikulum pembelajaran berdasarkan masalah. Ada enam keterbatasan, yaitu: 1) Hasil belajar akademik yang dicapai siswa melalui pembelajaran berdasarkan masalah. 2) Jumlah waktu yang dibutuhkan untuk implementasi. 3) Perubahan peran siswa dalam proses pembelajaran. 4) Perubahan peran guru dalam proses pernbelajaran. 5) Perumusan masalah-masalah yang sesuai. 6) Asesmen yang valid atas program dan pembelajaran siswa. (Nuh, 2008). Hal ini berarti keuntungan Problem Based Learning adalah proses pembelajaran lebih bermakna karena pemahaman dan keterampilan dalam konteks fungsional, mengembangkan keterampilan-keterampilan interpersonal dan kerja tim yang meningkatkan memotivasi pengarahan diri siswa.

Media adalah sesuatu yang membawa informasi dari sumber ke penerima. Media pembelajaran membawa pesan-pesan instruksional. (Heinich, 2002). Media Audiovisual berhubungan dengan indera penglihatan dan pendengaran. (Sadiman, 2008).

Belajar dapat direpresentasikan sebagai transfer informasi dari Short-Term Memory (STM) menuju Long-Term Memory (LTM) agar dapat disimpan dalam waktu yang lama dan dalam jumlah yang tidak terbatas. Salah satu cara seseorang memfasilitasi perolehan pengetahuan adalah pencitraan dengan melibatkan citra visual. (Reed, 2004). Masalah yang ditampilkan melalui media Audio-visual dalam Problem Based Learning akan menimbulkan pencitraan yang memfasilitasi siswa untuk mengalami pembelajaran dengan terjadinya transfer informasi dari STM menuju LTM.

Media pembelajaran Audio-visual adalah penggunaan video sebagai saluran komunikasi pembawa pesan instruksional berupa materi pelajaran dari guru yang diterima oleh indera penglihatan dan pendengaran siswa untuk merangsang pikiran, perasaan, perhatian dan minat siswa sehingga terjadi proses belajar.

\section{METODE}

Penelitian tindakan kelas dilaksanakan di SMA Negeri 10 Bogor, pada mata pelajaran Biologi semester 3 (tiga) tentang Sel dan Jaringan Tumbuhan. Agar lebih efektif, penelitian dilaksanakan berkolaborasi dengan seorang guru yang berperan sebagai observer dan peneliti bertindak sekaligus sebagai guru model. Subjek penelitian seluruh siswa kelas XI IPA 2 Tahun Pelajaran 2016/2017. Penelitian dilakukan dalam dua siklus, siklus I terdiri atas 2 kali tindakan dan siklus II terdiri atas 2 kali tindakan.

Faktor yang diteliti dalam penelitian tindakan kelas ini adalah siswa dan guru. Faktor siswa yang akan diteliti adalah pencapaian kompetensi Biologi dan keantusiasan belajar siswa. Pencapaian kompetensi Biologi meliputi penguasaan dimensi proses kognitif siswa 
dibandingkan dengan dimensi yang ditetapkan pada standar kompetensi.

Faktor guru yang akan diteliti adalah aktivitas dalam pengelolaan pembelajaran model Problem Based Learning dengan Audio-visual yang diukur melalui lembar observasi.

Jenis data yang didapat adalah data kualitatif dan data kuantitatif. Data kualitatif hasil observasi keantusiasan belajar siswa dan aktivitas guru dalam pengelolaan pembelajaran. Data kuantitatif kompetensi berupa nilai tes kompetensi kognitif.

Teknik pengumpulan data yang digunakan adalah tes dan observasi. Tes untuk mengukur kompetensi kognitif. Bentuk observasi yang dilakukan adalah observasi terstruktur karena menggunakan panduan lembar observasi yang telah dibuat yaitu lembar observasi keantusiasan belajar siswa dan lembar observasi aktivitas guru.

Teknik analisa data yang digunakan pada penelitian tindakan kelas ini analisis data deskriptif kualitatif dan kuantitatif. Dalam menganalisa hasil observasi keantusiasan belajar siswa dan aktivitas guru dengan cara menghitung persentase kategori untuk setiap tindakan, penilaian dilakukan oleh observer. Analisis data pencapaian kompetensi kognitif dilakukan secara kuantitatif dengan teknik rata-rata dan persentase.

\section{HASIL DAN PEMBAHASAN}

Hasil penelitian menunjukkan bahwa pada siklus I, hasil uji kompetensi kognitif siswa belum mencapai kriteria ketuntasan minimal yang telah ditetapkan. Kegiatan pembelajaran siklus II dilakukan dengan memperbaiki kelemahan yang ditemukan pada siklus I.

Pengelolaan pembelajaran model Problem Based Learning dengan media Audio-visual dapat meningkatkan keantusiasan belajar siswa. Keantusiasan belajar siswa pada siklus I tindakan 1 adalah 92\%, siklus I tindakan 2 adalah 97\%, pada siklus II tindakan 1 adalah 97\%, pada siklus II tindakan 2 adalah 98,\%. Peningkatan keantusiasan belajar siswa dari siklus I ke siklus II dapat meningkatkan kemampuannya untuk memahami materi pembelajaran. Peningkatan pemahaman siswa terhadap materi pelajaran tentu akan meningkatkan kompetensi kognitif siswa. Keantusiasan belajar berpengaruh terhadap ketercapaian kompetensi siswa. Sebuah model kapasitas mengasumsikan bahwa seseorang memiliki kontrol untuk mengalokasikan kapasitasnya pada kegiatan yang berbeda. Meskipun pendengar dapat mencoba untuk memahami makna dari dua pesan secara bersamaan, tetapi akan berakibat mengurangi kemampuannya untuk memahami pesan utama. (Reed, 2004).

Peran guru dijabarkan dalam tahap-tahap pembelajaran model Problem Based Learning. Hasil pengamatan terhadap guru, yaitu kesesuaian antara pelaksanaan aktivitas guru dalam pengelolaan pembelajaran dengan rencana yang dibuat untuk model Problem Based Learning dengan media Audio-visual. Aktifitas yang direncanakan sebagai implementasi model Problem Based Learning dengan media Audio- 
visual yang dilaksanakan guru pada siklus I tindakan 1 adalah $93 \%$, siklus I tindakan 2 adalah 100\%, dan siklus II tindakan 1 dan 2 adalah 100\%. Peningkatan pelasanaan aktifitas yang direncanakan sebagai implementasi model Problem Based Learning dengan media Audiovisual yang dilaksanakan guru dari siklus I ke siklus II menunjukkan pada proses pembelajaran model Problem Based Learning dengan media Audio-visual ini, guru telah berfungsi sebagai scaffolding atau kerangka pendukung untuk meningkatkan kompetensi siswa. Peran guru dalam model Problem Based Learning menyediakan scaffolding atau kerangka pendukung yang meningkatkan pertumbuhan intelektual siswa. (Arens, 2008)

Hasil uji kompetensi Pendidikan Biologi siklus I adalah 74 dan $67 \%$ siswa mencapai KKM sedangkan siklus II adalah 79 dan $77 \%$ siswa mencapai KKM. Berdasarkan nilai tersebut terlihat bahwa model Problem Based Learning dengan Media Audio-visual dapat meningkatkan kompetensi Biologi tentang Sel dan Jaringan Tumbuhan pada Siswa Kelas XI-IPA 2 SMAN 10 Bogor.

Peningkatan kompetensi Biologi dapat dilihat dari rata-rata hasil uji kompetensi kognitif pada siklus I adalah 74 meningkat menjadi 79 pada siklus II. Peningkatan rata-rata hasil uji kompetensi Biologi dari siklus I ke siklus II sehingga KKM terlampaui menunjukkan bahwa telah terjadi interaksi dalam pemecahan masalah pada model Problem Based Learning dengan media Audio-visual pada penelitian ini. Problem
Based Learning dapat meningkatkan kompetensi siswa dalam berbagai domain. (Kattington, 2010).

Penggunaan media Audio-visual dapat mengatasi keterbatasan ruang dan waktu pembelajaran. Media Audio-visual juga akan menimbulkan pencitraan yang memfasilitasi siswa untuk menyimpan pesan. Masalah yang ditampilkan berada dalam konteks dunia nyata sehingga mengandung unsur-unsur mediasi karena yang kehadirannya bermakna. Penggunaan media Audio-visual sangat tepat, hal ini terlihat dari peningkatan hasil uji kompetensi siswa dari siklus I ke siklus II. Salah satu kunci keberhasilan dalam menerapkan model Problem Based Learning adalah ketepatan dalam menentukan jenis masalah yang akan dibahas. (Duch, 2001).

Nilai tes kognitif siswa pada siklus I adalah 74, berarti belum mencapai Kriteria Ketuntasan Minimal (KKM) yang telah ditetapkan. Kegiatan pembelajaran siklus II dilakukan dengan memperbaiki kelemahan-kelemahan yang ditemukan pada siklus I.

Perbaikan dalam proses pembelajaran siklus II antara lain dari segi jumlah anggota kelompok. Dalam pembelajaran berbasis masalah karena siswa diminta untuk bekerja sama dalam menganalisis dan memecahkan masalah, untuk berkomunikasi, mengevaluasi, dan mengintegrasikan informasi dari berbagai sumber maka kelompok kecil dapat berdampak positif terhadap hasil belajar, ketekunan dan sikap terhadap belajar (Duch, 2001). 
Kelompok kecil lebih mengembangkan keterampilan-keterampilan interpersonal dan kerja tim yang meningkatkan pengarahan diri siswa. Agar terjadi peningkatan kompetensi maka jumlah anggota kelompok pada siklus II dikurangi.

Pada pembelajaran siklus I, siswa dikelompokkan menjadi enam (6) kelompok dengan anggota 6-7 orang perkelompok kurang efektif. Jumlah anggota kelompok terlalu banyak sehingga beberapa siswa setiap kelompok tidak berpartisipasi aktif dalam pembelajaran. Pada saat persentasi kelompok, hanya ketua kelompok yang maju ke depan, sedangkan anggota kelompok lain tetap duduk di tempat semula. Kondisi ini mengurangi rasa tanggung jawab siswa terhadap hasil kerja kelompok.

Pembelajaran pada siklus II jumlah anggota kelompok diperkecil, siswa dikelompokkan menjadi 10 kelompok dengan anggota 3-4 orang. Tata cara dan format bahan persentasi juga diperbaiki dengan cara semua anggota maju ke depan pada saat persentasi kelompok dan sebelumnya bahan persentasi diperiksa oleh guru agar memenuhi kriteria yang tepat.

Perbaikan lainnya yang dilakukan pada proses pembelajaran siklus II adalah menambahkan motivasi pada siswa. Motivasi adalah keinginan dan energi yang menggerakkan siswa untuk menyelesaikan tugas atau mencapai tujuan. Motivasi terutama berasal dari dalam diri, tapi dapat juga berupa kekuatan eksternal. (Kirby, 2009)

Untuk menambah keinginan dan energi eksternal yang menggerakkan siswa untuk tujuan pembelajaran maka observer mencatat nama siswa yang bertanya dan menjawab pertanyaan, serta memberikan penilaian langsung terhadap hasil persentasi kelompok dan siswa yang memberi tanggapan, Pertanyaan atau jawaban dengan tepat berupa bintang berwarna biru untuk nilai $\mathrm{A}$, bintang berwarna kuning untuk nilai $\mathrm{B}$, dan bintang berwarna merah untuk nilai $\mathrm{C}$.

Perubahan proses pembelajaran yang dilakukan pada siklus II berdampak positif terhadap hasil uji kompetensi kognitif siklus II sehingga berhasil melampaui KKM yang ditetapkan sebelumnya.

Berdasarkan data-data tersebut di atas, dapat disimpulkannya bahwa model Problem Based Learning dengan Media Audio-visual dapat meningkatkan kompetensi Biologi tentang Sel dan Jaringan Tumbuhan pada Siswa Kelas XI-IPA 2 SMAN 10 Bogor.

\section{KESIMPULAN}

Hasil temuan penelitian tindakan pada siklus I dan II dapat disimpulkan sebagai berikut:

Pengelolaan pembelajaran model Problem Based Learning dengan Media Audio-visual dapat meningkatkan kompetensiBiologi. Hasil uji kompetensi kognitif Biologi pada ulangan kenaikan kelas (UKK) di SMA Negeri 10 Bogor dalam tiga tahun terakhir, hanya 45\%, 60\%, dan $55 \%$ dari siswa yang mencapai KKM. Pada siklus I, rata-rata nilai uji kompetensi kognitif adalah 74 dan $67 \%$ siswa mencapai KKM. Pada siklus II, rata-rata nilai uji kompetensi kognitif adalah 79 dan $77 \%$ siswa mencapai KKM. Nilai uji 
kompetensi siklus II sudah mencapai kriteria ketuntasan minimal yang ditetapkan sebelumnya.

Model Problem Based Learning dengan Media Audio-visual dapat meningkatkan kompetensi Biologi jika implementasi model dalam proses pembelajaran menyebabkan terjadinya pencitraan, interaksi dan mediasi. Pada tahap awal Model Problem Based Learning dengan Media Audio-visual, guru menayangkan video untuk memunculkan masalah sebagai batu loncatan dalam menginvestigasi siswa. Pada saat siswa memperhatikan tayangan video, konsep Biologi yang abstrak berubah menjadi konkret sehingga mengandung unsur mediasi yang akan menimbulkan pencitraan guna memfasilitasi siswa untuk menyimpan pesan visual karena terbentuk hubungan antara materi pembelajaran dengan situasi nyata yang dihadapi dalam kehidupan sehari-hari. Video juga menimbulkan pencitraan, yaitu menciptakan citra visual untuk mengingat informasi verbal sehingga terjadi proses transfer informasi dari Short-term Memory (STM) menuju Long-Term Memory (LTM), tempat dimana informasi tersimpan dalam waktu yang lama dan dalam kapasitas tidak terbatas. Tahap selanjutnya, siswa berdiskusi dalam kelompok untuk menentukan masalah, siswa mengumpulkan informasi sebagai bahan untuk menyusun presentasi kelompok. Siswa mempresentasikan masalah berupa fakta-fakta sehingga menghasilkan solusi masalah. Selama diskusi terjadi interaksi yang melibatkan siswa dalam penyelidikan intelektual dalam mengembangkan keterampilan berfikir. Interaksi antar siswa lebih maksimal terjadi dalam kelompok kecil karena lebih mengembangkan keterampilan-keterampilan interpersonal dan kerja tim yang meningkatkan pengarahan diri siswa. Kapasitas kognitif seseorang dapat ditingkatkan melalui mediasi pengalaman belajar.

Problem Based Learning mengandung mengandung parameter interaksi mediasi, yaitu pemecahan masalah merupakan hasil interaksi, masalah berada dalam konteks dunia nyata dan kehadirannya bermakna. Untuk mengukur penguasaan siswa, setelah proses pembelajaran dilakukan uji kompetensi kognitif. Teknik penilaian uji kompetensi kognitif adalah tes tertulis dengan instrumen penilaian soal pilihan ganda (multiple choise). Hasil penilaian menunjukkan bahwa Model Problem Based Learning dengan Media Audio-visual dapat meningkatkan kompetensi siswa karena terjadinya pencitraan, interaksi dan mediasi dalam proses pembelajaran 


\section{DAFTAR PUSTAKA}

Arens, Richard I. Learning to Teach, terjemahan Helly Prayitno S. Yogjakarta: Pustaka Pelajar, 2008.

Biggs, Alton. Biology. New York: The McGraw-Hill Companies, Inc. , 2008.

Duch, Barbara J. The Power of Problem-based Learning. Virginia: Stylus Publishing, LLC Sterling, 2001.

Fogarty, Robin. Problem-based Learning. USA: IRI/Skylight Training and Publishing, Inc, 1997.

Forehand, Mary, "Bloom's Taxonomy", Emerging Perspectives on Learning, Teaching and Technology, $2011 \mathrm{http}: / /$ projects.coe.uga.edu

Glazer, Evan. "Problem Based-Instruction", Emerging Perspectives on Learning, Teaching and Technology, 2011. http://projects.coe.uga.edu/epltt

Heinich, Robert. Instructional Media and Technologies Learning. USA: The Lehigh Press, Inc. 2002.

Kattington, Limon E. Education in a Competitive and Globalizing World. New York: Nova Science Publishers, Inc, 2010.

Kirby, Elizabeth. Engage Every Student Motivation Tools for Teachers and Parents. Minneapolis: Search Institute, 2009.

L'Abate, Luciano. Relational Competence Theory. London: Springer, 2010.

Liu, Xiufeng. Linking Competence to Opportunities to Learn. USA: Springer Science, 2009.

Mohamad Nur. Model Pembelajaran Berdasarkan Masalah. Surabaya: Pusat Sains dan Matematika Sekolah UNESA, 2008.

O’Hagan, Kieran. Competence in Social Work Practice. London: Jessica Kingsley Publishers, 2007.

Oong-Seng, Tan. Enhancing Thingking through Problem-based Learning Approaches. Singapure: Cengange Learning, 2004.

Piscurich, George M. ASTD Models for Learning Technologies, Roles, Competencies, and outputs. Alexandria: Society for Training \& Development, 1998.

Evert, Ray F. Esau's Plant Anatomy Meristems, Cells, and Tissues of the Plant

Body: Their Structure, Function, and Development. New Jersey: John Wiley \&Sons Inc, 2006.

Reed, Stephan K. Cognition Theory and Aplications. USA: Thomson Learning Inc, 2004.

Sadava, David. Life The Science of Biology . Tanzania: Sinauer Associates, Inc. , 2 